\title{
POWER PLAY IN THE CHURCH? THE CASE OF 1 TIMOTHY 2:8-15
}

\author{
P.H.R. (Rob) van Houwelingen \\ Theologische Universiteit Kampen \\ Correspondence: phrvanhouwelingen@tukampen.nl
}

\begin{abstract}
Thinking in terms of ecclesiastical power as a negative force has often found a breeding ground in the Pastoral Epistles. To what extent is that justified? This article examines a passage that always comes up when the position of women in the church is discussed: 1 Timothy 2:8-15. Three aspects will be considered consecutively: power, powerlessness, and authorized power. Power says something about the underlying problem that Timothy faced: the male/female relationship in the Ephesian congregation threatened to degenerate into a power struggle. Powerlessness refers to the story of Adam and Eve mentioned in verses 13-15. The Genesis narrative recounts human weakness, which in 1 Timothy becomes a sort of triptych about Eve and creation, Eve and the fall, and Eve and redemption. Authorized power is the way in which the problematic situation in Ephesus was regulated with apostolic authority, to create space for the trustworthy Word. Paul's instructions about the behaviour of women could nowadays easily be considered a kind of misogynistic power play. However, the apostle should be interpreted on his own terms. This is true both for his social context and for his missionary drive.
\end{abstract}

KEYWORDS: power, man, woman, congregation, Paul

\begin{abstract}
ABSTRAK: Berpikir dari segi kuasa gerejawi sebagai kekuatan negatif sering ditemukan perkembangannya dalam surat-surat pastoral. Sejauh mana itu dibenarkan? Artikel ini membahas suatu perikop yang selalu muncul ketika posisi perempuan di gereja dibahas: 1 Timotius 2:8-15. Tiga
\end{abstract}

\footnotetext{
1 This article is a pre-publication of a contribution in the forthcoming volume Power in the New Testament, edited by Annette Merz \& Pieter G.R. de Villiers (CBET; Leuven: Peeters, 2020). It contains reworked exegetical material from Van Houwelingen (2013). An earlier version in Dutch has been published in HTS Theological Studies 68.1 (2012), Art. \#1023, 9 pages, http://dx.doi.org/10.4102/hts.v68i1.1023.
} 
aspek akan dipertimbangkan secara berurutan: kekuasaan, ketidakberdayaan, dan kekuasaan yang disahkan. Kekuasaan mengatakan sesuatu tentang masalah mendasar yang dihadapi Timotius: hubungan laki-laki/ perempuan di sidang Efesus mengancam untuk merosot menjadi perebutan kekuasaan. Ketidakberdayaan mengacu pada kisah Adam dan Hawa yang disebutkan dalam ayat 13-15. Narasi Kejadian menceritakan kelemahan manusia, yang dalam 1 Timotius menjadi semacam triptych tentang Hawa dan penciptaan, Hawa dan kejatuhan, dan Hawa dan penebusan. Kekuasaan resmi adalah cara di mana situasi bermasalah di Efesus diatur dengan otoritas kerasulan, untuk menciptakan ruang bagi Firman yang dapat dipercaya. Instruksi Paul tentang perilaku wanita saat ini dapat dengan mudah dianggap sebagai semacam permainan kekuatan misoginis. Namun, rasul itu harus ditafsirkan dengan persyaratannya sendiri. Ini berlaku baik untuk konteks sosialnya dan untuk dorongan misionarisnya.

KATA KUNCI: kuasa, pria, wanita, jemaat, Paulus

\section{Introduction}

During the rise of Christianity, various social relationships developed within the earliest communities. These relationships involved the members of the various congregations: Jew and Gentile, slave and free, male and female (according to Gal 3:28), as well as their leaders: the apostles and their co-workers, elders and deacons/deaconesses. If the term 'power' means 'every opportunity within a social relationship to assert one's will even against opposition', as the widely used definition of Max Weber puts it, then one can speak of ecclesiastical power, that is: power based on a position of authority within an ecclesiastical context. This power can function either as a positive or as a negative force. ${ }^{2}$

Thinking of ecclesiastical power as a negative force has often found a breeding ground in the Pastoral Epistles. ${ }^{3}$ In particular, publications of authors using analytical tools from gender studies have increased the sensitivity of contemporary scholars to the topic of male-female power relationships and the reception history of the Pastorals in entrenching gender inequality (E.g. Wagener 1994; Merz 2004; Bourland Huizenga 2013).

\footnotetext{
See further e.g. Appleby (2000).

The common label 'Pastoral Epistles' is widely used, although some scholars prefer the designation LTT (Letters to Timothy and Titus) to underline that these documents are in fact individual compositions, dealing with common themes. See on this topic the special issue of the Journal for the Study of Paul and His Letters 9.1-2 (2019).
} 
Most scholars are of the opinion that the letters to Timothy and Titus originated during a later stage in early Christianity. In that case, Paul himself would not have shown evidence of abusing ecclesiastical power. Reading the Pastoral Epistles as post-Pauline documents is not the only possibility, though. The letters to Timothy and Titus could also contain instruction from the apostle Paul to his co-workers. If Paul was the author of the Pastoral Epistles, ecclesiastical power becomes an even larger issue. Could the above-mentioned gender inequality in the Christian church, as a negative force of power, have begun with Paul himself? Or did the apostle exercise his apostolic authority as a positive force, a transforming power, in order to socialize communities according to a new value system based on the reality of Jesus Christ and the Kingdom of God (Ehrensperger 2007)?

Exploring whether and in what respect the Pastoral Epistles demonstrate thinking in terms of ecclesiastical power, the present article will examine an important passage: 1 Timothy 2:8-15. This passage is always discussed when it comes to the role of women in the church. Paul's introduction to 1 Timothy mentions that he is writing this letter to his spiritual son, Timothy, who was responsible for the congregation in Ephesus. In the following essay, a cursory exegesis of 1 Timothy 2:8-15 will be presented, by means of a close reading of the text within the corpus paulinum, including the self-attestation of 1 Timothy as a letter of the apostle Paul. If Paul's authorship is not acknowledged and the letter is assumed to be pseudepigraphal, the same text must still be interpreted (Van Houwelingen 2013, 9-36).

Three aspects of 1 Timothy 2:8-15 will be considered: power, powerlessness, and authorised power. Under the heading Power, the underlying problem is discussed that Timothy faced: the male/female relationship within the congregation in Ephesus that threatened to degenerate into a power struggle (section 1). With Powerlessness, the creation account as referred to in verses 13-15 comes into view. Its focus is the woman God created, Eve. The Genesis narrative tells the story of human weakness, which in the first letter to Timothy becomes a sort of triptych about Eve and the creation, Eve and the fall, and Eve and redemption. From all this, Paul draws the conclusion that a woman is not allowed to teach in the church or to exercise authority over a man (section 2). Finally, Authorised power refers

\footnotetext{
Donfried (2008) advocates a scientific reevaluation of 1 Timothy by making use of different research traditions and research perspectives. On the textual claim of Pauline authorship, see Klinker-De Klerck (2013); Wilder (2010); Barentsen (2011, 185-200); Walter (2012, 4-16, 120-32); Thiessen (2016, ch. 4-5); Van Nes (2017). In early Christianity, pseudepigraphy was not a legitimately accepted literary convention, contrary to what is often assumed today. If pseudepigraphy was discovered, the document was rejected because the truth may never be supported by a(n author's) lie (Baum 2001; Wilder 2004; Porter \& Fewster 2013). From a quite different perspective, see Ehrman (2013)..
} 
to speaking with another's authority -in Paul's case, as an ambassador of Jesus Christ. Paul wanted to regulate a problematic situation involving male/female relationships in Timothy's congregation by giving his apostolic

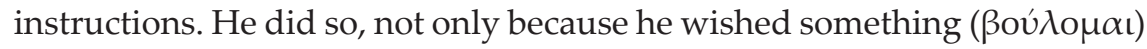

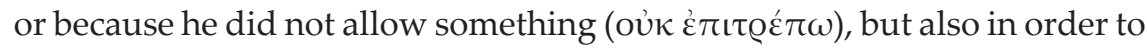
create space for the trustworthy Word (section 3 ).

The discussion of 1 Timothy 2:8-15 will be completed with a conclusion and reflection.

\section{Power}

Paul begins chapter 2 with his peace-engendering church order for the Christian congregation. He seems to have the local church in mind as he goes on to provide rules involving the male/female relationship. The Christian congregation exists in the world as a house of prayer. People assemble in this house to pray together for all people. Such joint prayers also engender peace among church members. Therefore, living peaceful and quiet lives has an external as well as an internal focus; indeed it has a societal as well as an ecclesiastical effect (verses 1-2). After this 'exhortation' pertaining to outsiders, Paul gives his instructions regarding believers' interaction with each other. First he calls attention to the behaviour of men and women separately (verses 8-10). Then he gives his directions for the mutual relationships between male and female in regard to their conduct during worship meetings (verses 11-15). His underlying argument seems to be that all unrest will disappear from the congregation when the members together draw near unto God. Moreover, through such worship the house of prayer will radiate the peace of harmonious relationships.

\section{Male Behaviour}

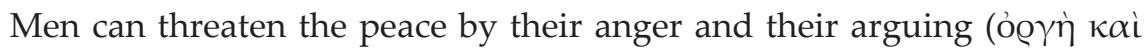

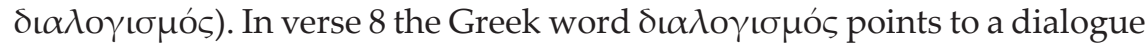
with a negative connotation: a "difference of opinion". This word can be understood as having doubts or objections, indicating that a person has conflicting views (see Bauer \& Aland 1988, 372; followed by Oberlinner 1994, 86; Neudorfer 2004, 118, referring to Phil 2:14). However, the use of

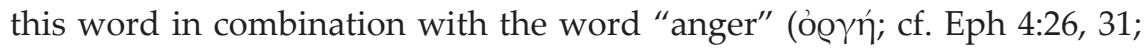
$\mathrm{Col} 3: 8)$ points more in the direction of "having a difference of opinion with others". It could very well be that the two terms complement each other, indicating that Paul wants to say that aggressiveness leads to division. Is he perhaps referring to cultural stereotypes of male competitive behaviour? In 
any case, Paul is concerned that especially with men, the result will be that the prayer he has prescribed will be hampered by such clashes. According to verse 8 , hands lifted up in prayer could prevent such division and would lead to true union and communion.

What Paul wants to communicate is that anger and disunity have no place in a praying congregation. Someone who prayerfully commends all people unto God does not have his hands free for taking out his anger on his neighbour or for heavy-handedly settling arguments with others. Such behaviour would desecrate prayer and actually render it impossible (Matt 5:23-34; Jas 4:1-3, 8). David Scholer (2003) suggests that false teachers were causing anger and discord. Yet, the text does not provide an adequate basis for that suggestion. The point is that devotion to God has consequences: neighbours must be treated with love. Traditionally, males were deemed to be spokesmen in the synagogue as well as in the civic assembly. Therefore Paul assumes that only men would lead in prayer during worship meetings of the Christian congregation. This does not negate the fact, however, that according to Paul women could actively lead in prayer and could prophesy outside worship meetings (Anderson 2008, 150-55; contra Zamfir \& Verheyden 2008). Besides, Paul subsequently writes about the behaviour of women in 1 Timothy 2:9-10, indicating that they did participate in congregational prayer. In antiquity, in certain groups people were not used to engaging jointly in worship as men and women, so tensions could easily arise in settings where both sexes were present (Quinn \& Wacker 2000, 207). Perhaps for this reason, Paul felt it necessary to give appropriate instructions for both groups: men receive a guideline for prayer; women receive a dress code. In both cases, then, Paul is furnishing an apostolic rule of conduct for the assembled congregation when they are praying together in congregational prayer for all people (verses 1-2).

\section{Female Behaviour}

"Likewise [I desire] also that women should adorn themselves in respectable apparel." Paul connects his dress code for women in the congregation to his prayer-instruction for men rather simply. He does so by using the conjunction "likewise" (strengthened by the word "also" according to most

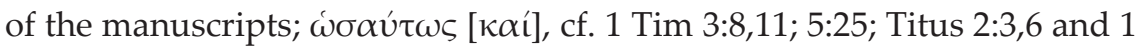
Cor 11:25). The reader intuitively looks back to verse 8 in order to find the main verb that will complete this elliptical sentence; then it becomes clear that in regard to the women as well, Paul is explaining what he as an apostle 
wants from them. ${ }^{5}$ Some interpreters still want to add a form of the verb 'to pray'. The Greek sentence structure, however, does not require such an addition. Here the apostle is not providing a special prayer instruction, although he is undoubtedly continuing to keep a praying congregation in view (Van Neste 2004, 39-40).

A Christian woman may adorn herself with all sorts of fine clothing and jewelry (1 Pet 3:5; Rev 21:2). Yet, Paul insists that her adornment must fit the occasion. She should not make herself a spectacle by means of elaborate coiffures, gold, pearls, and expensive apparel. What is most important for her must be her inner self, which she would express outwardly by means of a specific hair style and dress style. Paul succinctly characterizes such

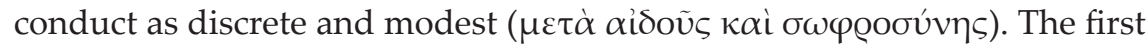
epistle of Peter gives a similar instruction directly to Christian women who were living in the same region of Asia Minor: "Your beauty should not come from outward finery, such as braided hair and the wearing of gold, jewelry and fashionable clothes. Instead, it should be that of your inner disposition, the unfading beauty of a gentle and quiet spirit. God greatly delights in such beauty" (1 Pet 3:3-4). ${ }^{6}$

The prescribed dress code in 1 Timothy should not be understood as being limited to married women (contra Hugenberger 1992). There was no such a limitation with regard to the preceding prayer instruction for men, either. Besides, if married women were being addressed, one would expect an additional modifier, like "their women". Furthermore, in chapter 5 Paul writes that unmarried widows also belonged to the congregation. It seems that this passage is addressing rich women in particular. They could afford the luxury of wearing an elaborate hairdo, jewelry inlaid with gold or precious stones, and an expensive wardrobe. Their houses were most likely large enough to generously accommodate (a part of) the Christian congregation as a place for meeting and praying. So then, in these houses believers should focus on worship. However, hostesses wearing luxurious cosmetics or clothing or jewelry would be drawing attention to themselves, and would thereby distract from the purpose of prayer.

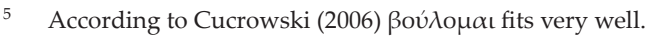

6 Batten $(2009,499)$ discusses the social-cultural background of both texts. Especially for women who were viewed as living a domestic life, luxurious clothes and jewelry were useful items for demonstrating great economic power and prestige. She concludes: "The author may wish for women to dress modestly in the context of worship in particular because he is concerned about the status indicators that women's wealth display could exhibit, especially among other women, thereby enhancing female significance and roles in the community overall. Thus limiting their adornment functions doubly to protect the community from external criticism and internally, to thwart any attempts women were making to maintain or enhance their leadership roles.".
} 
A possible background for this instruction could be that around the first century C.E. a new type of woman emerged, as Bruce Winter (2003) has argued. ${ }^{7}$ This type of woman had come from elite society and an established family, leading her to act as a 'free woman'. She was recognizable by hairstyle, clothing, and jewelry. Moral philosophers in antiquity, like Plutarch, Seneca, and Epictetus, sharply criticized this development as an alarming emancipation movement. They saw this as a threat not only to the stability of family life, but also to life in society as a whole. However, Winter overstates his case: in Asia Minor the prominence of women was noticeable only on the western coast. ${ }^{8}$ Nevertheless, although this type of 'free woman' was not as popular and prevalent as Winter supposes, this phenomenon could have influenced people, particularly in major cities like Rome and Ephesus. Paul concurs with the warning of the moral philosophers. He wants to prevent the rich Christian women in the Ephesian congregation from provocative behaviour.

There may be a word play in the Greek text of verses 9-10: for Christian

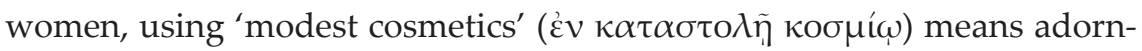

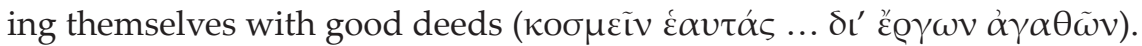
According to 1 Timothy 6:18 one can also be rich in good works ( $\dot{\alpha} \gamma \alpha \theta \dot{\alpha} ; 5: 10$ identifies some practical examples of good works done by older widows ). Good deeds are a personal adornment that would not make women from the Christian congregation look bad, as Paul notes by interjecting the words "what is proper for women who profess godliness". When a person claims to be a confessing Christian, that person must continue to put into practice his/her confession in everyday life. The term used for "godliness" ( $\theta \varepsilon$ coбé $\beta \varepsilon \iota \alpha)$ appears in the New Testament only in this passage. The book of Acts regularly characterizes non-Jewish adherents of the synagogue - many of whom were women - as "worshippers of the true God". ${ }^{9}$ In this context, Paul is thinking particularly of women taking part in worship meetings and their involvement in congregational praying. By doing so, they are professing their Christian faith. Godliness will become evident by adorning oneself with qualitatively good deeds. Because virtuous acts will be appreciated, the focus will be on God and one's neighbour.

\footnotetext{
Revelation 17:3-5 (cf. 18:16) records a visionary description of a gaudy Roman woman: "The woman was arrayed in purple and scarlet, and adorned with gold, precious stones and pearls". Thus in all its luxurious decadence Rome is being portrayed as the new Babylon.

Dixon (2005). Merz (2019) is very critical on Winter's argument. For the position of women in Asia Minor, see Trebilco (1991, 104-26) and Trebilco (2004, 11-52,507-28). Clothes were a key element of the symbolic systems of Roman civilization, for women as well as men (Olson 2008). God's will.

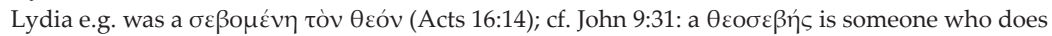


From the above it should be clear that Paul's dress code for women must not be taken as a Christian directive for good manners, as if it were sufficient to be dressed tastefully and decently for attending worship meetings and for praying. For men as well as for women it is important, according to the apostle, to be aware of what drives them when they approach God. Hottempered men and richly dressed women would be focussed too much on themselves, thus making it impossible for them to pray properly for others (verses 1-2). From a praying congregation that desires to draw near unto God respectfully, the apostle expects devoted hands dedicated to the Lord as well as handsome deeds honouring him.

\section{Men and Women in Relation to One Another}

Having dealt with the conduct of men and women separately, Paul now turns to discuss their conduct in relation to one another. In this connection, the apostle declares that a woman is not permitted to teach or exercise authority over a man when the Christian congregation is assembled for worship (1 Tim 2:11-12). His use of the singular man/woman indicates that he is speaking generically, in line with the example of Adam and Eve that immediately follows.

Attempts have been made to connect Paul's use of the singular to one specific woman. She would then be described as an Eve-type in Ephesus (Spencer 1974; cf. Hamilton 2000). However, such attempts are forced, since the Greek uses the singular not only for the woman but also for the man. Neither is the apostle addressing the marriage relationship exclusively. He is discussing the male/female relationship in the context of a congregation gathered for worship.

Paul considers quietness important for women. They must allow themselves to be taught in quietness, says verse 11; and they must remain quiet, according to verse 12 ( $ү \sigma v \chi i ́ \alpha$ is repeated). Only a quietly listening attitude makes a person receptive. Here quietness does not mean being totally silent, but it refers to the disposition of compliance: to live and to work without complaining, just as the praying congregation as a whole should lead a "peaceful and quiet life" (verse 2; cf. 1 Thess 4:11; 2 Thess 3:12). Self-assertion is especially a source of unrest, in Paul's view. He advocates in its place a listening posture, in which all the attention is focused on the instruction being given. So, in the learning situation within the Christian congregation, the role of a quiet student is assigned to the woman. The identity of the one giving the instruction is not indicated. Paul's direction with regard to women, viz., that they need to know their place ( $\dot{\varepsilon} \vee$ vं reflects the usual situation in antiquity of a male teacher and students who 
can be either male or female. All students need to conform to the teaching situation, which means that compliance is the most appropriate attitude.

The Mishna shows that the rabbis differed about whether it should be recommended that a father instruct his daughter in the Torah (Sota 3:4). Every Jewish child had to live according to the laws and rules of Judaism. As one would expect, they needed to get acquainted with the basic requirements of the Torah. For boys, ongoing instruction in the Torah was a mandatory part of their religious nurture. Mothers raised their girls with a view to domestic work and to their future marriage. The father had to decide what to do to further his daughter's studies in the Torah. In Greco-Roman culture, women usually had access to certain forms of education, which was certainly the case for upper class women. ${ }^{10}$ To the women of the Christian congregation Paul emphasizes the need to learn ( $\mu \alpha v \theta \alpha ́ v \varepsilon เ v$; cf. 2 Tim 3:14; Titus 3:14). They are not allowed to give instruction in Christian doctrine

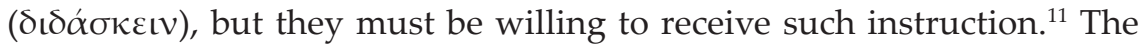

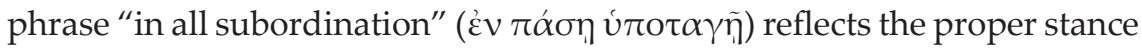
of learners toward teachers in ancient educational enterprises, and perhaps also the subordination of women to men, especially the male teachers who are allowed to teach in the assemblies (Bourland Huizenga 2013, 281-82). This is Paul's instruction, then: "I do not permit a woman to teach and, in combination with this, contrary to her subordinated position, to assume authority over a man; she must be quiet."

The meaning of the verb $\alpha \dot{u} \theta \varepsilon v \tau \varepsilon \tilde{\imath} v$ in verse 12 is difficult to establish. Before the New Testament period, this word was used only sporadically. Baldwin has done extensive lexicographical research on this word; he identifies a range of five basic meanings: to rule, to control/to dominate, to exercise authority, to act independently, and, in later texts, to commit murder (Baldwin 2005; cf. Burk 2016). ${ }^{12}$ The fact that Paul combines such an unusual

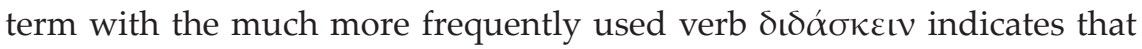
here he wishes, by way of clarification, to introduce an additional nuance in meaning. ${ }^{13}$ Within the framework of the male/female relationship in the

10 For this entire paragraph, see further Ilan $(1995,190-204)$. Estep $(2011,84-85)$ suggests that in the Greco-Roman approach to education, "schools were intended for boys, but girls were permitted to attend, although fewer attended than boys". Therefore, the distinction between access and participation must be stressed (cf. Krumbiegel 2013).

11 For Paul, instruction in Christian doctrine is closely connected with the practise of everyday life (e.g. Rom 16:17; 1 Cor 14:31; Eph 4:20; Phil 4:9; Col 1:7; Titus 3:14). Sometimes this instruction apparently was controversial: some people propagated deviating beliefs (1 Tim 1:3). On Crete even unacceptable things were being taught (Titus 1:11). Timothy therefore receives a teaching charge from Paul, which Timothy in turn had to pass on to reliable men (1 Tim 4:11; 6:2-3; 2 Tim 2:2).

12 The dictionary of Louw \& Nida (1989, domain 37) describes the semantic field to which $\alpha \dot{v} \theta \varepsilon v \tau \varepsilon \tilde{\imath} v$

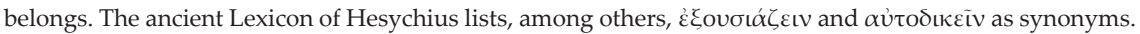

13 Köstenberger (2016) tries to prove that the Greek grammatical construction with oủ $\delta$ ć coordinates 
church, the activity of teaching has a negative connotation: women should not abuse the teaching-learning situation by trying to take control. An authoritarian attitude would disturb the desired "rest" of the congregation gathered for worship. ${ }^{14}$

It must be observed that the male/female relationship was not always an issue. Older women were allowed to instruct younger women (Titus 2:3). In Ephesus, Priscilla together with her spouse Aquila had been intensively involved in giving Apollos fuller teaching about the way of God (Acts 18:26). Furthermore, prophetesses were active as well (Acts 21:9; 1 Cor 11:5). Moreover, every church member could make his or her contribution to the worship meeting (1 Cor 14:26). As was shown in the discussion of verses 9-10, women too participated in congregational praying. Paul, however, does not allow women to teach in the meetings of the congregation, nor to participate actively in a public discussion during a teaching-learning situation in the church. At that specific moment they are not permitted to assume the man's position. Also in ecclesiastical settings it must become clear that Christians lead a peaceful and quiet life, as this goal was stated in verse 2 .

To understand the situation the apostle is addressing, one has to realize that at this time three developments were occurring, and each development strengthened the impact of the other two. First, we see the ambition of wealthy women to physically (by their clothing) and verbally (by their teaching) assert themselves over against the other sex. That was a form of taking control, which could cause serious unrest during congregational meetings. Secondly, we see the possibility that such women would be stirred up by false teachers into doing exactly that. Those false teachers were seeking to promote their heretical views (hence the charge of "capturing silly

activities of the same order, that is to say, activities that are either both viewed positively or negatively by the writer. He wishes to value positively both teaching as well as exercising authority, so that Paul is denying to woman both activities though they are worthwhile in themselves. Marshall $(1999,458)$ holds an opposing view. Considering the context, he states that precisely the reverse is the case: the activity of teaching by women is judged as something negative; consequently the same would be true regarding women's aspiration to rule over men by teaching them. The activity of $\alpha \dot{v} \theta \varepsilon v \tau \varepsilon \tilde{\varepsilon} v$ has a negative connotation. From Titus 1:11 ("teaching objectionable things") it appears that the activity of $\delta\llcorner\delta \alpha \sigma \kappa \varepsilon เ v$ is not valued by Paul as merely something positive. Payne (2008) disputes the opinion of Köstenberger, demonstrating that syntactic constructions with oủk + oủdé $+\dot{\alpha} \lambda \lambda \alpha$ are normally used to combine two elements over against something else (Polybius, The Histories XXX 5,8; Josephus, Jewish Antiquities 7,127). Paul uses such a construction eleven times: Rom 2:28-29; 9:6-7,16; 1 Cor 2:6-7; Gal 1:1,11-12,16-17; 4:14; Phil 2:16-17; 2 Thess 3:7-8; 1 Tim 2:12 (cf. John 1:13). The only instance in which two distinct elements can be discerned (2 Cor 7:12) still shows a self-evident relation between the two. Payne paraphrases: "I am not permitting a woman to teach and [in combination with this] to assume authority over a man" (253). By way of explanation, one could add that Paul considered a woman teaching to be contrary to a woman's subordinate position.

14 Blomberg (2001) points out that in this letter, Paul more often uses partially synonymous words or expressions. Thus in this case $\delta\llcorner\delta \alpha \sigma \kappa \varepsilon เ v$ obtains more colour from the words $\alpha \dot{\theta} \theta \varepsilon v \tau \varepsilon \tilde{\imath} v \dot{\alpha} v \delta \varrho o ́ s$. Paul does not allow women to tell men what to do. For more lexicographical research on the meaning of the

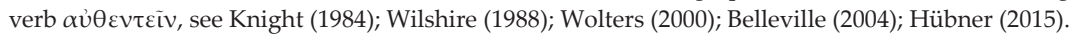


women"; 2 Tim 3:6). In the third place, a type of trendy 'free woman' was emerging in Rome and expanding throughout the empire, functioning as a sort of role model for female independence. This trend could have influenced the women of the Christian congregation in Ephesus. In the context of a teaching-learning situation in which men and women together received instruction in Christian doctrine, the male/female relationship was particularly sensitive.

Reasoning in this way, the apostle Paul operates within the patriarchal structures of Greco-Roman society (mirrored in the Christian congregation), in which women should remain silent in public. He wants to prevent Christians from giving offense to outsiders and thereby erecting unnecessary barriers to the wholesome social impact of the gospel (cf. Du Toit 2012). Consequently, the Christian community may not tolerate any kind of internal power struggle.

\section{Powerlessness}

Verses 13-15 from 1 Timothy 2 explain why thinking in terms of ecclesiastical power is wrong. Paul discusses the relationship between the very first man and woman, and their susceptibility to temptation, demonstrating their powerlessness against the influence of sin. Thus considered, primeval history is a story of human weakness. The reference from the creation account on which Paul bases his argument is not an exact quotation from Scripture (contra Krause 2004, 60-62; Van Oyen 2011). Rather, this reference functions as a recollection of the story of Adam and Eve in the garden of Eden. It evokes questions like: Is Paul using an argument limited to this occasion? Or: Is the apostle referring to a normative structure that God has embedded in creation? Or even: Is Paul intending here to implicitly oppose a certain heresy, for example, the view that by nature woman is superior to man? ${ }^{15}$

\section{The story of Adam and Eve}

One obtains an important insight into the structure of the text, and therefore also into its meaning, when one understands verses 13 and 14 together with verse 15a as belonging to Paul's reference to the story of Adam and Eve (cf. Mulder 1988; Wall 2004; Towner 2006, 233). The basis for this insight is the following:

1. The subject of verse $15 \mathrm{a}$ is the same as in verse 14: "the woman" († $\gamma v v \eta$, note the use of the definite article) who in verse 13 was called Eve (the

15 Depending on the answers to these questions, differing conclusions are drawn about the functioning of women in the Christian church today (Beck 2005; Van Houwelingen 2014, 2015; Gench 2015). 
name Adam later gave her);

2. The term $\tau \varepsilon \kappa v o \gamma$ oví $\alpha$ in verse $15 \mathrm{a}$, unique in the New Testament, alludes

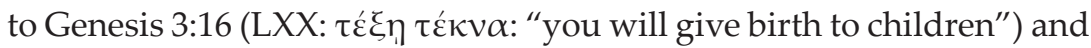

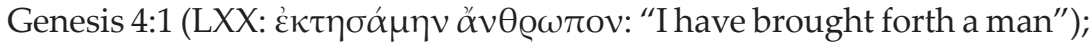

3. The plural of the verb is used in verse $15 b$, not earlier; thus, verse $15 a$ must be grammatically connected to the preceding sentence.

With regard to the pure male/female relationships within the Christian church, Paul is referring back to the beginning of humanity: the creation, fall, and redemption of the first human couple, Adam and Eve. Surprisingly enough, he is viewing primeval history from the perspective of the woman. Viewed in this way, Genesis provides a narrative of human powerlessness. Eve was created after Adam; the woman let herself be deceived and therefore fell into transgression. However, she will find salvation in her motherhood (in verse 15a the translation should be "she", i.e., Eve). This is not to say that Adam bore no guilt for the fall, nor that men do not stand in need of redemption. It does mean, however, that women from the congregation will be able to discover both their origin and their destiny as daughters of Eve. To exercise domination over men would, according to Paul, reverse the sequence in which man and woman were created. It would also promote deception that leads to sin against God, endangering redemption through Jesus Christ (see 2:4). Therefore the apostle's counsel is: continue in faith, love, and holiness, together with modesty, the virtue that was mentioned

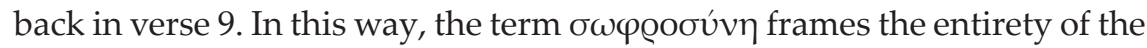
apostle's prescriptions with respect to women. ${ }^{16}$

The references to creation, fall, and redemption are connected to each other as follows:

- Creation (verse 13): "For Adam was formed first, then Eve";

- Fall (verse 14): "And Adam was not deceived, but the woman was deceived and became a transgressor";

- Redemption (verse 15a): "She will be saved through childbearing".

\section{Eve and Creation}

"Then the LORD God formed the man from the dust of the earth and breathed into his nostrils the breath of life and the man became a living being" (Gen 2:7). There is a terminological link between the Genesis creation narrative and Paul's reference to it in verse 13. This is evident by his use

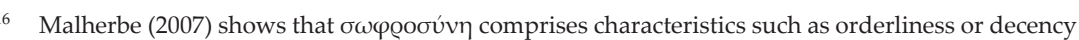
and neatness; it has to do with self-respect, a sense of good judgment, and controlling the tongue; in brief, $\sigma \omega \varphi$ Qoбúv $\eta$ exactly suits the context of 1 Tim 2:8-15 (cf. Bourland Huizenga 2013, 339-43). 
of the verb "to fashion" or "to form" to refer to God's actual creation work ( $\pi \lambda \dot{\alpha} \sigma \sigma \varepsilon v v ;$ cf. Rom 9:20). In the Genesis narrative, this verb is not repeated when Eve appears alongside Adam. However, later accounts of the creation of humanity as male and female do describe it that way (cf. 2 Macc 7:23; Josephus, Antiquities 1,32; 1 Clement 33:4). With his own hand the Creator fashioned the first human couple. Later Eve received her deeply significant name that would give hope in a world plagued by death: Eve represents life, so she became the mother of all living (Gen 3:20). Thus, God himself had brought to life this human couple: first Adam, then Eve.

Some commentators claim that Paul's reference belongs to a wellknown rabbinic tradition of interpretation (e.g. Roloff 1988, 139). If that were the case, Paul would have been using here a line of thought limited to this occasion. Michael Mulder, however, did not find a similar reference in Jewish sources (Mulder 1988, 182-84). We do know that in Jewish-Hellenistic literature one often takes one's cue from the common notion that something created first must have a higher value (Strack \& Billerbeck 1924, 256-58, 645-46; Küchler 1986, 21-30; Pilhofer 1990). The first one would be the better one. Nowhere else, however, is this argument of giving priority to the first one applied to the male/female relationship. Paul can say something about the mutual relationship between man and woman from the perspective of creation (1 Cor 11:8-9). Apparently he can do the same with regard to how men and women must interact with each other. Paul interprets the sequence of creation events in terms of rank, reading the Genesis narrative in line with existing social patterns regarding the male/female relationship. The first human couple came into this world in a sequence that the Creator had determined: first Adam, then Eve. In Paul's view, it would turn the world upside down if, by her teaching, a woman would exercise dominion over a man.

\section{Eve and the Fall}

"God the LORD asked the woman: 'What is this you have done?' The woman said: 'The serpent deceived me, and I ate"' (Gen 3:13). Once again, a lexical similarity to Genesis can be observed by means of the term "to deceive". Here the Septuagint uses two cognate forms of this verb ( $\dot{\alpha} \pi \alpha \tau \tilde{\alpha} v$ with Adam and $\dot{\xi} \xi \alpha \pi \alpha \tau \tilde{\alpha} v$ with the woman). The Genesis narrative speaks of the devil's deception through the serpent only in connection with the woman and not with Adam. Therefore Paul could warn the Corinthians that the serpent cunningly deceived Eve (2 Cor 11:3). When in his letter to Timothy Paul deals with the male/female relationship, he emphasizes that it was Eve who let herself be deceived. Thereby the wife of Adam "became a transgressor" 
( $\pi \alpha \varrho \alpha \alpha \beta \alpha \sigma \varsigma:$ overstepping the bounds). In stating this, Paul is not denying that Adam also was responsible for having sinned (Rom 5:12-19; cf. 1 Cor 15:21-22). ${ }^{17}$ Nevertheless, his wife was too ambitious: she so desperately wanted to be like God that she could not resist the temptation. ${ }^{18}$

In connection with this reference of Paul to Genesis, people often think of the influence of Jewish exegetical traditions (Roloff 1988, 139; references in Küchler 1986, 33-35). Attention is drawn to the wisdom of the apocryphal book Sirach: "Sin started with woman; through her we all must die" (Sir 25:24). However, that statement was made in the context of an extensive warning against malicious women, who were making their husbands extremely unhappy. The quote does not concern the male/female relationship as such. ${ }^{19}$ If an already existing Jewish tradition about this topic could be identified, then it was less specific than Paul's instruction, according to Mulder (1988, 185): "Nowhere is the fall of Eve used as a basis for a general authoritative relationship between men and women. Such a connection is not even alluded to".${ }^{20}$ So, Paul is making a unique theological contribution to the interpretation of Genesis. ${ }^{21}$

\section{Eve and Redemption}

"Adam named his wife Eve, because she would become the mother of all the living" (Gen 3:20; cf. 3:16: "with pain you will give birth to children," and 4:1b reads: "With the help of the LORD I have brought forth a man"). Here the connection with Genesis is present first of all in terms of content, that is to say, through the name given to the woman; for the name "Eve" points to life. Furthermore, a semantic similarity can also be observed, considering the

17 In The life of Adam and Eve, a Jewish text from the first century C.E. that seems to have been very popular in early Christianity, the first human couple deplore the consequences of their sin against God. At the deathbed of Adam, Eve addresses their children and grandchildren (Apocalypse 15-30). She finishes by saying: "Now then, my children, I have shown you the way in which we were deceived. But you watch yourselves so that you do not forsake the good" (Charlesworth 1985, 287).

18 In Jewish and early Christian traditions, the opinion is repeatedly expressed that Eve's deception involved especially sexual seduction by the serpent (Küchler 1986, 44-50). The text, however, does not support that idea. The intensive verb $\dot{\varepsilon} \xi \alpha \tau \alpha \tau \tilde{\alpha} v$ ("deceive thoroughly") used with respect to women cannot be considered as evidence, since Paul always uses this verb for spiritual deception (Rom 7:11; 16:18; 1 Cor 3:18; 2 Thes 2:3). But what is striking is that Eve does not first consult either her husband and/or her Creator regarding the serpent's suggestion. She acted on her own when she let herself be deceived. Even so, Paul does not say that by such action Eve was assuming authority over Adam. Contra Moo (1991).

19 The unnamed female in Sirach 25:24 is identified, almost universally, as the biblical Eve. For objections to this identification, see Ellis (2011).

20 Quote translated from the Dutch. Stratton (1996) speaks about "a variety of perspectives on women and on Eve's role in the garden story." (262).

21 In connection with Genesis 3:1, Philo answers the question why the serpent did not address the man but the woman, by stating that the woman was more susceptible to deception than the man, since she was gentler in heart (Questions and Answers on Genesis I 33). 1 Timothy 2, however, gives a different explanation. 


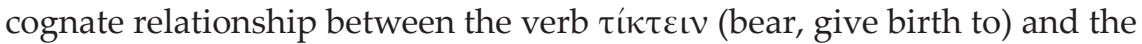
rare noun $\tau \varepsilon \kappa v o \gamma o v i ́ \alpha$. In Genesis this noun is used twice with the definite article (literally: the birthing of a child). With this rare noun Paul is referring to the woman as the one who becomes pregnant and brings offspring into

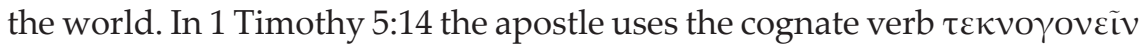
to say that younger widows should remarry and have children. In verse 15 the implicit subject of the phrase "she will be saved" is identical to the phrase "the woman" in verse 14. She is the one who, in this passage from verse 13 onward, is the one bearing the name Eve. Thus, according to Paul, Eve the mother of all the living will be saved by having children.

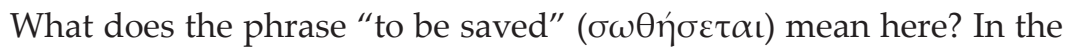
Pastoral Epistles the term "salvation" always has a spiritual meaning. Thanks to God's grace, sinners can be saved (1 Tim 1:15; 2:4; 4:16; 2 Tim 1:9; 4:18; Titus 3:5). Eve had transgressed God's commandment and thereby brought the death penalty upon herself. Nevertheless, she would not perish in the future judgment. God promised that she would have offspring (Gen 3:15). In response to this promise, Adam gave the name "Life" to this woman. The motherhood of Eve would be a sign of life, the life that she was privileged to pass on to subsequent generations. Down through the centuries, she has brought forth numerous children, sons and daughters. Eve is the mother of the entire human race. Paul states that her life is ultimately saved along the path of motherhood. God our Saviour will forgive her transgression for the sake of her children. ${ }^{22}$ This is precisely the message of the gospel: the mediator between God and humanity, Christ Jesus, gave himself as a ransom for all people (1 Tim 2:5-6a). He paid with the price of his life, not only for Eve's children but also for their mother. ${ }^{23}$

22 The bearing of children is not a means unto salvation for the woman. She does not save herself ( $\sigma \omega \theta \eta \dot{\eta} \sigma \varepsilon \tau \alpha \iota$ is passive). The phrase $\delta \dot{\alpha} \tau \tilde{\eta} \varsigma \tau \varepsilon \kappa \nu 0 \gamma o v i ́ \alpha \varsigma$ must be understood instrumentally, as the way by which her salvation takes place. The real Saviour of humanity is none other than God through his son Jesus Christ. Salvation therefore is no safety device, in the sense of merely physically enduring a difficult pregnancy and surviving the process of giving birth (Keener 1992, 118-20; taking up a suggestion from

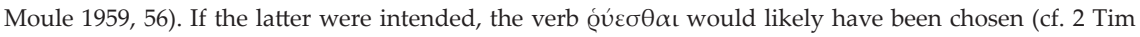
$3: 11 ; 4: 18)$. Neither is salvation here freedom, which means: being delivered from the power of Satan who seeks to deceive people (according to Köstenberger (1997), who refers to 1 Tim 3:6-7; 5:15; 2 Tim 2:26. In fact, Satan was not mentioned in verse 14 at all. Women's virtuousness cannot be the meaning of salvation, either (cf. Waters 2004; he interprets children allegorically as the four virtues mentioned in verse 15b); for salvation cannot possibly be realized and maintained through oneself.

23 A popular explanation links the term $\tau \varepsilon \kappa v o \gamma o v i ́ \alpha$ to a particular child that would be born in the future, namely, Jesus. Eve had the privilege of paving the way for the birth of the Messiah and that child would save her (see Spencer 1974; Knight 1984; Baumert 1992, 229-30). It is true that this interpretation explains the definite article and the future tense, but $\tau \varepsilon \kappa v o \gamma$ oví $\alpha$ says more about the bearing of a child than about the child born. Moreover, Genesis 3:15 speaks collectively about offspring and about an ageold struggle. Therefore in our preceding explanation, a broader interpretation is being developed. As the mother of humanity Eve would also become the mother of Mary and thus also of Jesus Christ (cf. Gal 4:4; $\operatorname{Rev} 12: 5)$. 


\section{Eve and Her Children}

A specific condition is formulated in the last part of verse 15: "...if they continue in faith, love, and holiness with prudence". Salvation is coupled with the Christian life. A difficult problem is how this datum must be connected with the first part of this verse. Who is or are actually referred to? In verse $15 \mathrm{a}$ the verb is in the singular, with the grammatical antecedent "the woman" ( $\eta \gamma v v \eta$ ) from verse 14. However, in Greek the subject of the conditional subordinate clause of verse 15b, "if they remain" ( $\dot{\varepsilon} \dot{\alpha} v \mu \varepsilon \dot{v} v \omega \sigma \iota v)$, is in the plural. Two different solutions are proposed:

a. The construction of verse 15 can be understood as a "constructio ad sensum". That is a grammatical construction in which the predicate agrees not with the grammatical form of the subject, but with its meaning. Different from verses 13 and 14, the woman of verse 15 must be taken in this case as kind of a collective noun referring to women. This distinction is expressed by the use of the plural in the subordinate clause. These women, then, must continue in faith, love, and holiness with self-control.

b. The construction of verse 15 can be understood as an ellipsis (where a word is omitted that would otherwise be necessary for a complete grammatical construction), where the term $\tau \varepsilon \kappa v o \gamma$ oví $\alpha$ ("childbearing") almost automatically makes one think of children. The transition from the singular to the plural marks the difference between the one mother and the many children. These children brought into the world by the woman must continue in faith, love, holiness, and self-control (in Greek one could perhaps complete the sentence by adding $\tau \dot{\alpha} \gamma \varepsilon v \nu \eta \theta \varepsilon \dot{v} \tau \alpha)$.

Both solutions are defensible. Although nowadays most scholars choose option (a), according to Anne-Marie Malingrey (1975) the Greek church fathers unanimously chose option (b). The church fathers believed that the last part of verse 15 implicitly pointed to the importance of nurturing children, and to the perseverance in the faith that the younger generation often must learn. In the Pastoral Epistles much attention is given to nurturing in the faith (1 Tim 3:4; Titus 1:6 and 2:4). Timothy had received his faith from his grandmother Lois and from his mother Eunice (2 Tim 1:5). This interest of the Pastoral Epistles in Christian nurture, along with the history of exegesis, gives option (b) a slight advantage.

Based on the identification of the woman with Eve, as was proposed in the exegesis of verses 11-15a, another interpretation can be suggested. This possibility combines options (a) and (b) with regard to the woman and children. The children are the children of Eve who must continue in faith, love, and holiness with self-control. In this case, Paul has in mind the women of 
the congregation as Eve's children, whom he actually always has in view in the verses $9-15 .{ }^{24}$ The apostle does not talk about their children. The women themselves are the children! The mother of all living will ultimately be saved if the women of the church as her daughters continue to conduct themselves in a manner that befits mature Christians. ${ }^{25}$

The familiar Christian ethical duo of faithfulness and love (cf. 1 Tim 1:14; Titus 2:2) is mentioned in verse $15 b$ together with holiness ( $\dot{\alpha} \gamma\llcorner\alpha \sigma \mu$ ós; cf. 1 Thess 4:3). In this way a series of three Christian virtues appears. Paul concludes the series of three virtues with the inclusion of a keyword from verse 9 as a fourth virtue. He repeats that word on purpose at the end of the sentence: with self-control ( $\mu \varepsilon \tau \dot{\alpha} \sigma \omega \varphi \varrho 0 \sigma u ́ v \eta \varsigma)$. For the apostle this appears to be the most important characteristic of all the believing daughters of Eve. With a lifestyle of self-contol, the women of the church could show that they do not want to transgress God's command as their mother Eve once did. Instead, they want to persevere ( $\mu \varepsilon \varepsilon v \varepsilon เ v$; cf. 2 Tim 3:14) in faith, love, and holiness. Such a life, of course, is not the route to salvation, but one that followed and imitated Christ Jesus, who came into the world to save sinners. Then their lives will also ultimately be saved.

Of course, not only women belong to Eve's believing children, but the men do as well. In the next pericope the requirement will be established that male overseers must be "self-controlled" ( $\sigma \omega \varphi \rho \omega v ; 1$ Tim 3:2; cf. Titus 1:8). The apostle Paul writes all of this in order to prevent disorder within the Christian congregation. By ending his biblical reference to the conduct of Adam and Eve with the desired conduct of Eve's children, male as well as female, the apostle returns to the main line of his argument. Sobriety or self-control must characterize the relationships between men and women when they have assembled together to pray to God. This is true for the other Christian virtues as well. Over against all aggressiveness within the church, this code of conduct prescribed by Paul can create peace: a rest consisting of harmonious relationships. ${ }^{26}$

241 Peter 3:6 has a similar instruction to the Christian women of Asia Minor, pointing to the example of Sarah, the wife of Abraham. She always showed her husband due respect. "You are her daughters if you do what is right and do not give way to fear". The similarity to Eve's children is the more striking since the context of 1 Peter 3 presents a parallel with the dress code for women in 1 Timothy 2 . This is the best way of showing themselves true daughters.

25 Holmes (2000) believes that the subject of if they continue is both Adam and Eve: by having children the man and the woman can overcome their rivalry by carrying out their mutual responsibility. Holmes thinks that verses 13-15 are not further developing verses 11-12, but they serve to bring the whole chapter to a close; the chapter does not deal with the conduct of men and women during the church's worship meetings but with their conduct in daily life. In order to be able to maintain her view she must, however, classify the conjunctive $\gamma \alpha \dot{Q} \varrho$ in verse 13 as redundant (the verses $13-15$, equated with the trustworthy Word (3:1a), would have been cited from a Jewish source).

26 For various models of explanation of the historical background of verse 15b, see Merz (2004, 
Paul seems to be operating within the parameters of a hierarchically structured society. From this perspective, he interprets the sequence of creation events (first Adam, then Eve) as a sequence of rank, and with this he supports his instruction that women are not allowed to teach in the church. The actual situation was that they had less power than men, both in the Christian congregation and in the surrounding society. Yet, Paul communicates that being daughters of Eve, that is to say, living a Christian life, is very promising. Eve and all her children, whether female or male, will be saved through her divine descendant, Jesus Christ.

\section{Authorised Power}

On what basis is Paul writing all of this? In 1 Timothy 2:7 he had said that he was appointed ( $\dot{\tau} \varepsilon \dot{\varepsilon} \theta \eta v$, a passivum divinum, pointing to his divine calling by Christ Jesus [1 Tim 1:12]) as a herald and ambassador of the apostolic witness. At first sight, this self-presentation looks pleonastic. Margaret Mitchell (2008) therefore thinks that it serves to authenticate the specific role of the pseudonymous Paul. However, it is equally possible that the real Paul wanted to accentuate his apostolic authority before giving instructions about the behaviour of men and women in the church. The emphatic $\dot{\varepsilon} \gamma \omega$ stresses his personal involvement. In addition to that, he also gives himself

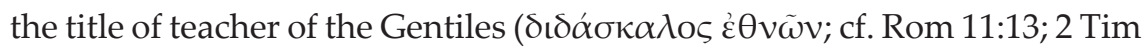
$1: 11)$. He has an authoritative teaching role. Paul's instruction regarding men and women is being placed within the framework of his apostleship, ultimately authenticated by the God who wants all people to be saved and to come to a knowledge of the truth (verse 4). As an apostle, he feels entitled to use his authorised power in a positive way.

In the passage under discussion, Paul once again picks up the thread of his prescriptions. Since he is appointed to be an apostle, Paul speaks with the authority of the Lord when he points out how he wants members to conduct themselves within the congregation ( $\beta$ oú $\lambda$ o $\mu \alpha$ เ oũv takes up $\pi \alpha \varrho \alpha \kappa \alpha \lambda \tilde{\omega}$ oũv from verse 1). In Ephesus Timothy had to act as Paul directed him to do. By concretely working out the problematic case of women wanting to teach men, Paul is once again acting as an apostle. He is doing so with self-evident

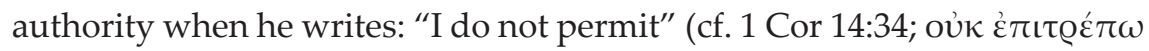

303-33). It is often supposed that women were targets of false teachers, who disputed specific aspects of the traditional role of the woman in marriage, sexuality, and motherhood (e.g. Van der Jagt 1988; Schlarb 1990, 278-79, 333; Kimberley 1992; Porter 1993; Wagener 1994, 107-9). The Kroeger couple defends the view that Paul is opposing a Gnostic heresy in Ephesus. This heresy pointed to Eve in order to argue that a woman has natural superiority over the man. Thus according to the Kroegers Paul is here using an argument limited to the original occasion (Kroeger \& Kroeger 1999, 59-66). Their opinion has been opposed by Schreiner (2016), who holds the view that Paul's words are based on the creation order. 
in verse 12 is the opposite of $\beta o u ́ \lambda \circ \mu \alpha \iota$ o $v$ v in verse 8).

\section{At Every Place of Worship}

As is typical for Paul, he writes in verse 8 that these prescriptions are valid

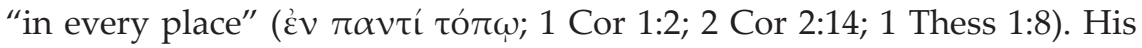
concern is not restricted to the local house congregations in Ephesus that were under Timothy's responsibility. On the contrary, the universal scope of prayer presupposes a global church that can be found in many places. Partly as a result of Paul's apostolate, there are now people everywhere in the world who call upon the name of the Lord (cf. Mal 1:11, cited in Didache 14:1-3). Thus the expression "in every place" means: in every place of prayer, where Christians meet for worship. God's salvation is not only intended for all people but it also becomes public in all places. However, Paul does not envisage a hierarchically organised world church. His apostolic prescriptions are intended for a local church organisation, guided by people from their own community.

\section{Space for the Trustworthy Word}

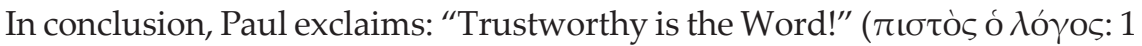
Tim 3:1a). This phrase can be taken as belonging to what follows; however, under the influence of the newer text editions of Nestle-Aland, interpreters increasingly prefer to connect this phrase to Paul's preceding instruction (Schlarb 1998, 209-9; Quinn \& Wacker 2000, 234-35; Johnson 2001, 203; Collins 2002). Three reasons can be given for this choice. First, a semantic

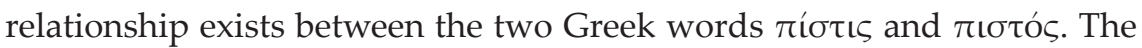
Christian faith, as Eve's children must continue to practise it in trustworthy faithfulness, is based on the Word that always remains trustworthy. Second, in this passage Paul had included references to creation, fall, and redemption. For Eve's role in all that, but also for the deliverance promised to her and her children, the apostle can refer to the Word that is trustworthy and deserves our full acceptance. Christ Jesus came into the world to save sinners (1 Tim 1:15). Third, any connection with the conditional sentence in verse $1 \mathrm{~b}$ must be regarded as hardly plausible. Campbell (1994) tries to avoid that problem by reading 1 Timothy 3:16 as being introduced by the phrase of verse 1a. However, such an arch-like construction would be without a parallel. The phrase "trustworthy is the Word" does not introduce a quotation but provides firm ground beneath the feet (see Van Houwelingen 2011, 90-91 n. 28). Paul is using the power of content. He does not come with a power-word as his argument, but by means of this instruction for his co-worker 
Timothy he creates space for the trustworthy Word.

\section{Conclusion and Reflection}

From the case of 1 Timothy 2:8-15, three exegetical observations have become apparent. First of all, Paul is not crafting his arguments from particular, local circumstances when he regulates the behaviour of men and women in the Christian congregation. Although Ephesus was dominated by its Artemis cult, in comparison with other ancient cities its situation was not exceptional (Baugh 2016 contra Gritz 1991; Hoag 2015). Originating in Rome, the type of the 'free woman' emerged in the main cities of the Empire, particularly among the well-to-do. The provocative behaviour of wealthy Christian women could have been one of the reasons for Paul's specific instructions to his co-worker Timothy, the pastor of the congregation in Ephesus. Furthermore, as far as we know the apostle does not derive his line of thought from a Jewish tradition of interpretation. Nor does he cite any textual proof from Genesis, but points to the historical role of Eve in connection with creation, fall, and redemption. By doing so, Paul placed his church order, which aims at rest and peace (verses 1-2), in a redemptive-historical framework. Finally, human relationships are sensitive and vulnerable, not least within the church. Jesus Christ, the descendant of Adam and Eve, was born into the world to save sinners and to sanctify the male/female relationship, which means purging it from the impact of evil.

Further reflection is needed on the impact of power and power relationships in the Christian church. The danger of thinking in terms of ecclesiastical power is always lurking around the corner, particularly regarding the way tasks are distributed among men and women within a believing community. As a house of prayer in the world, the church is not the most suitable place for playing power games. The opening history of humanity, with our primeval mother Eve as a main character, tells the story of human weakness. Humanity would never make it without God. Paul instructs his co-worker Timothy about the tension-prone male/female relationship during meetings of the church in Ephesus. Both sexes were present at the same time and in the same space - thanks to the transforming power of the gospel. This special setting of worship occasioned Paul's emphasis on rest and peace. By requiring women to be silent, while men were allowed to teach, the apostle followed the conventions of Greco-Roman society. A believing community that wants to be missional does not erect unnecessary barriers for outsiders.

Whereas Paul was mainly concerned about domination by women, modern Western society with its sensitivity to gender equality is more sensitive to domination by men. From this viewpoint, Paul's instructions about 
the behaviour of women in the church could easily be considered a kind of misogynistic power play. However, the apostle should be interpreted on his own terms. This is true both for his social context and for his missionary drive. Pointing to tranquility in the church, Paul de facto confirmed the social situation of his time. Nevertheless, he was always conscious of his calling to proclaim Christ Jesus as the one Mediator between God and humanity. Spreading this gospel throughout the world he regarded to be his first and foremost task. Paul was not thinking in terms of ecclesiastical power, which aims at maintaining the status quo. His missionary drive and sensitivity to outsiders should be recognised and may motivate many contemporary Christians. The overall message of 1 Timothy 2:8-15 for today seems to be that, since God is the center of attention during congregational meetings for worship, it is not appropriate that people - from any social position - thrust themselves into the foreground or control each other.

It will remain a continuing challenge to preserve the church in all times and places in different contexts with the trustworthy Word.

\section{Bibliography}

Anderson, R.D. 2008. 1 Korintiërs. Orde op zaken in een jonge stadskerk. Commentaar op het Nieuwe Testament. Kampen: Kok.

Appleby, R. S. 2000. The Ambivalence of the Sacred: Religion, Violence, and Reconciliation. Lanham: Rowman \& Littlefield.

Baldwin, H.S. 2005. An Important Word: Av่ $\theta \varepsilon v \tau \varepsilon \dot{\omega} \omega$ in 1 Timothy 2:12. Pages 39-51 in Women in the Church. An Analysis and Application of 1 Timothy 2:9-15. 2nd ed. Edited by A.J. Köstenberger and Th.R. Schreiner. Grand Rapids: Eerdmans.

Barentsen, J. 2011. Emerging Leadership in the Pauline Mission. A Social Identity Perspective on Local Leadership Development in Corinth and Ephesus. Princeton Theological Monograph Series. Eugene: Pickwick Publications.

Batten, A.J. 2009. Neither Gold nor Braided Hair (1 Timothy 2.9; 1

Peter 3.3): Adornment, Gender and Honour in Antiquity. New Testament Studies 55:484-501.

Bauer, W., and B. Aland. 1988. Griechisch-deutsches Wörterbuch zu den Schriften des Neuen Testaments und der frühchristlichen Literatur 6th ed. Berlin: De Gruyter.

Baugh, S.M. 2016. A Foreign World: Ephesus in the First Century. Pages 25-64 in Women in the Church. An Analysis and Application of 1 Timothy 2:9-15. Edited by A.J. Köstenberger and Th.R. Schreiner. 3rd ed. Wheaton: Crossway. 
Baum, A.D. 2011. Pseudepigraphie und literarische fälschung im frühen Christentum. Tübingen: Mohr Siebeck.

Baumert, N. 1992. Frau und Mann bei Paulus. Überwindung eines Mißverständnisses. Würzburg: Echter.

Beck, J.R., ed. 2005. Two Views on Women in Ministry. Revised Edition. Grand Rapids: Counterpoints.

Belleville, L. 2004. Teaching and Usurping Authority. 1 Timothy 2:1115. Pages 205-23 in Discovering Biblical Equality. Complementarity without Hierarchy. Edited by R.W. Pierce and R.M. Groothuis. Downers Grove: InterVarsity.

Blomberg, C.L. 2001. Neither Hierarchalist nor Egalitarian: Gender Roles in Paul. Pages 329-72 in Two Views on Women in the Ministry. Edited by J.R. Beck and C.L. Blomberg. Grand Rapids: Zondervan.

Bourland Huizenga, A. 2013. Moral Education for Women in the Pastoral and Pythagorean Letters. Philosophers of the Household. Supplements to Novum Testamentum 147. Leiden: Brill.

Burk, D. 2016. New and Old Departures in the Translation of in 1 Timothy 2:12. Pages 279-96 in Women in the Church. An Analysis and Application of 1 Timothy 2:9-15. 3rd ed. Edited by A.J. Köstenberger and Th.R. Schreiner. Wheaton: Crossway.

Campbell, R.A. 1994. Identifying the Faithful Sayings in the Pastoral Epistles. Journal for the Study of the New Testament 54:73-86.

Charlesworth, J.H., ed. 1985. The Old Testament Pseudepigrapha. Vol. 2. London: Darton, Longman \& Todd.

Collins, R.F. 2002. I \& II Timothy and Titus. A Commentary. The New Testament Library. Louisville: Westminster John Knox Press.

Cuckrowski, K.L. 2006. An Exegetical Note on the Ellipsis in 1 Timothy 2:9. Pages 232-38 in Transmission and Reception: New Testament Text-Critical and Exegetical Studies. Edited by J.W. Childers and D.C. Parker. Piscataway: Gorgias.

Dixon, S. 2005. Review of B.W. Winter, Roman Wives, Roman Widows. The Appearance of New Women and the Pauline Communities. Journal of Theological Studies 56.2:558-61.

Donfried, K.P. 2008. Rethinking Scholarly Approaches to 1 Timothy. Pages 153-82 in 1 Timothy Reconsidered. Edited by K.P. Donfried. Leuven: Peeters.

Du Toit, A.B. 2012. Sensitivity Towards the Reaction of Outsiders as Ethical Motivation in Early Christian Paraenesis. HTS Theological Studies 68.1:1-7. 
Ehrensperger, K. 2007. Paul and the Dynamics of Power: Communication and Interaction in the Early Christ-Movement. London: T\&T Clark.

Ehrman, B.D. 2013. Forgery and Counterforgery: The Use of Literary Deceit in Early-Christian Polemics. Oxford: Oxford University Press.

Ellis, T.A. 2011. Is Eve the "Woman" in Sirach 25:24? The Catholic Biblical Quarterly 73.4:723-42.

Estep jr., J.R. 2011. Women in Greco-Roman Education and Its Implications for 1 Corinthians 14 and 1 Timothy 2. Pages 80-93 in Women in the Biblical World: A Survey of Old and New Testament Perspectives. Volume 2. Edited by E.A. McCabe. Lanham: University Press of America.

Gench, F.T. 2015. Beyond Textual Harassment: Engaging Tyrannical Texts (1 Timothy 2:8-15). Pages 1-18 in Encountering God in Tyrannical Texts: Reflections on Paul, Women, and the Authority of Scripture. Louisville: Westminster John Knox.

Gritz, S.H. 1991. Paul, Women Teachers, and the Mother Goddess at Ephesus. A Study of 1 Timothy 2:9-15 in Light of the Religious and Cultural Milieu of the First Century. Lanham: University Press of America.

Hamilton, D.J. 2000. Do Not Permit a Woman to Teach. Pages 205-16 in Why not Women? A Fresh Look at Scripture on Women in Missions, Ministry, and Leadership. Edited by L. Cunningham and D.J. Hamilton. Seattle: YWAM Publishing.

Hoag, G.G. 2015. Wealth in Ancient Ephesus and the First Letter to Timothy: Fresh Insights from Ephesiaca by Xenophon of Ephesus. Wiona Lake: Eisenbrauns.

Holmes, J.M. 2000. Text in a Whirlwind: A Critique of Four Exegetical Devices at 1 Timothy 2.9-15. Sheffield: Sheffield Academic Press.

Hübner, J. 2015. Revisiting $\alpha \dot{\theta} \theta \varepsilon v \tau \varepsilon \dot{\omega} \omega$ in 1 Timothy 2:12: What Do the Extant Data Really Show? Journal for the Study of Paul and his Letters 5.1:41-70.

Hugenberger, G.P. 1992. Women in Church Office: Hermeneutics or Exegesis? A Survey of Approaches to 1 Tim 2:8-15. Journal of the Evangelical Theological Society 35:341-60.

Ilan, T. 1995. Jewish Women in Greco-Roman Palestine. An Inquiry into Image and Status. Tübingen: Mohr, 1995.

Johnson, L.T. 2001. The First and Second Letters to Timothy. A New Translation with Introduction and Commentary. The Anchor Bible. New York: Doubleday.

Keener, C.S. 1992. Paul, Women \& Wives. Marriage and Women's Ministry in the Letters of Paul. Peabody: Hendrickson.

Kimberley, D.R. 1992. 1 Tim. 2:15: A Possible Understanding of a Difficult Text. Journal of the Evangelical Theological Society 35:481-86. 
Klinker-De Klerck, M. 2013. Pastoral Rule or Lesson in Assimilation? Dissertation and Monograph Summary. Journal for the Study of Paul and His Letters 3.2:263-68.

Knight III, G.W. 1984. A $\Theta E N T E \Omega$ in Reference to women in 1 Timothy 2.12. New Testament Studies 30:143-57.

Köstenberger, A.J. 1997. Ascertaining Women's God-Ordained Roles: An Interpretation of 1 Timothy 2:15. Bulletin of Biblical Research 7:107-44.

Köstenberger, A.J. 2016. A Complex Sentence: The Syntax of 1 Timothy 2:12. Pages 117-62 in Women in the Church. An Analysis and Application of 1 Timothy 2:9-15. 3rd ed. Edited by A.J. Köstenberger and Th.R. Schreiner. Wheaton: Crossway.

Krause, D. 2004. 1 Timothy. Readings: A New Biblical Commentary. London: T\&T Clark.

Kroeger, R.C., and C.C. Kroeger. 1992. I Suffer Not a Woman. Rethinking 1 Timothy 2:11-15 in Light of Ancient Evidence. Grand Rapids: Eerdmans.

Krumbiegel, F. 2013. Erziehung in den Pastoralbriefen. Ein Konzept zur Konsolidierung der Gemeinden. Leipzig: Evangelische Verlagsanstalt.

Küchler, M. 1986. Schweigen, Schmuck und Schleier: drei neutestamentliche Vorschriften zur Verdrängung der Frauen auf dem Hintergrund einer Frauenfeindliche Exegese des Alten Testaments im antiken Judentum. Göttingen: Vandenhoeck \& Ruprecht.

Louw, J.P., and E.A. Nida, eds. 1989. Greek-English Lexicon of the New Testament Based on Semantic Domains. Vol, 1-2. Cape Town: Bible Society of South Africa.

Malherbe, A.J. 2007. The Virtus Feminarum in 1 Timothy 2:9-15. Pages 45-65 in Renewing Tradition. Studies in Texts and Contexts in Honor of James W. Thompson. Edited by M.W. Hamilton et al. Eugene: Pickwick Publications. Malingrey, A.-M. 1975. Note sur l' exégèse de I Tim. 2,15. Studia Patristica 12:334-39.

Marshall, I.H. 1999. The Pastoral Epistles. International Critical Commentary. Edinburgh: T\&T Clark.

Merz, A. 2004. Die fiktive Selbstauslegung des Paulus. Intertextuelle Studien zur Intention und Rezeption der Pastoralbriefe. Göttingen: Vandenhoeck \& Ruprecht.

Merz, A. 2019. 'New' Woman ? Bruce W. Winters These und ihre Rezeption in der exegetischen Diskussion kritisch beleuchtet. Pages 209-34 in Frauen im antiken Judentum und frühen Christentum. Edited by J. Frey and N. Rupschus. Tübingen : Mohr Siebeck.

Mitchell, M.M. 2008. Corrective Composition, Corrective Exegesis: The Teaching on Prayer in 1Tim :1-15. Pages 41-62 in 1 Timothy Reconsidered. 
Edited by K.P. Donfried. Leuven: Peeters.

Moo, D.J. 1991. What Does It Mean Not to Teach or to Have Authority over Men (1 Timothy 2:11-15). Pages 179-93 in Recovering Biblical Manhood and Womanhood. Edited by J. Piper and W. Grudem. Wheaton: Crossway Books.

Moule, C.F.D. 1959. An Idiom-Book of New Testament Greek. Cambridge: Cambridge University Press.

Mulder, M.C. 1988. 'En daarna Eva'. Over het schriftberoep van Paulus, met name in 1 Timoteüs 2: 11-15. Pages 174-200 in Vrouwen op een zij-spoor? Emancipatie van de vrouw en het verstaan van de Schrift in gereformeerd perspectief. Edited by J.M. Aarnoudse et al. Amsterdam: Buijten \& Schipperheijn.

Neudorfer, H.W. 2004. Der erste Brief des Paulus an Timotheus. HistorischTheologische Auslegung. Wuppertal: Brockhaus.

Oberlinner, L. 1994. Die Pastoralbriefe I. Herders theologischer Kommentar zum Neuen Testament. Freiburg: Herder Verlag.

Olson, K. 2008. Dress and the Roman Woman: Self-presentation and Society. New York: Routeledge.

Payne, P.B. 2008. 1 Tim 2.12 and the Use of oúdé to Combine Two Elements to Express a Single Idea. New Testament Studies 54:235-53.

Pilhofer, P. 1990. PRESBYTERON KREITTON. Der Altersbeweis der jüdischen und christlichen Apologeten und seine Vorgeschichte. Wissenschaftliche Untersuchungen zum Neuen Testament 2/39. Tübingen: Mohr.

Porter, S.E. 1993. What Does it Mean to be 'Saved by Childbirth'? Journal for the Study of the New Testament 49:87-102.

Porter, S.E., and G.P. Fewster, eds. 2013. Paul and Pseudepigraphy. Leiden: Brill.

Quinn, J.D., and W.C. Wacker. 2000. The First and Second Letters to Timothy. Eerdmans Critical Commentary. Grand Rapids: Eerdmans.

Roloff, J. 1988. Der Erste Brief an Timotheus. Evangelisch-Katholischer Kommentar zum Neuen Testament. Zürich/Neukirchen-Vluyn: Benziger.

Schlarb, E. 1990. Die gesunde Lehre. Häresie und Wahrheit im Spiegel der Pastoralbriefe. Marburg: N.G. Elwert Verlag.

Scholer, D.M. 2003. 1 Timothy 2:9-15 and the Place of Women in the Church's Ministry. Pages 98-121 in A Feminist Companion to the DeuteroPauline Epistles. Feminist Companion to the New Testament and Early Christian Writings. Edited by A.-J. Levine and M. Blickenstaff. Cleveland: Pilgrim.

Schreiner, Th. R. 2016. An Interpretation of 1 Timothy 2:9-15. Pages 163-226 in Women in the Church. An Analysis and Application of 1 Timothy 2:9-15. 3rd ed. Edited by A.J. Köstenberger and Th.R. Schreiner. Wheaton: 
Crossway.

Spencer, A.D.B. 1974. Eve at Ephesus. Journal of the Evangelical Theological Society 17.4:215-22.

Strack, H.L., and P. Billerbeck. 1924. Kommentar zum Neuen Testament aus Talmud und Midrasch. Band III. München: C.H. Beck.

Stratton, B.J. 1996. Eve through Several Lenses: Truth in 1 Timothy 2:8-15. Pages 258-73 in The Hebrew Bible in the New Testament. Edited by A. Brenner. A Feminist Companion to the Bible. Sheffield: Sheffield Academic Press.

Thiessen, J. 2016. Die umstrittenen Paulusbriefe - Abschriften und Fälschungen? Intertextuelle, literarkritische und theologische Studien. Mit zwei Ergänzungen von Rüdiger Fuchs. Zürich: Lit Verlag.

Towner, P.H. 2006. The Letters to Timothy and Titus. The New International Commentary on the New Testament. Grand Rapids: Eerdmans.

Trebilco, P. 1991. Jewish Communities in Asia Minor. Cambridge: Cambridge University Press.

Trebilco, P. 2004. The Early Christians in Ephesus from Paul to Ignatius. Tübingen: Mohr Siebeck.

Van der Jagt, K. 1988. Women are Saved through Bearing Children: A Sociological Approach to the Interpretation of 1 Timothy 2:15. Pages 288-95 in Issues in Bible Translation. Edited by P.C. Stine. London: United Bible Societies.

Van Houwelingen, R. 2011. A Godfighter Becomes a Fighter for God. Pages 83-100 in Coping with Violence in the New Testament. Edited by P.G.R. de Villiers and J. W. van Henten. STAR-series 16. Leiden: Brill.

Van Houwelingen, P.H.R. 2013. Timoteüs en Titus. Pastorale instructiebrieven. 3rd ed. Commentaar op het Nieuwe Testament. Kampen: Kok.

Van Houwelingen, R. 2014. Meaning and Significance of Paul's Injunction About Women in 1 Timothy 2:11-15: A Response to Gerhard Visscher. Pages 155-67 in Correctly Handling the Word of Truth. Reformed Hermeneutics Today. Edited by G.H. Visscher and M. te Velde. Eugene: Wipf \& Stock.

Van Houwelingen, R. 2015. Meaning and Significance of the Instruction about Women in 1 Timothy 2:12-15. Sárospataki Füzetek 19.4:59-71.

Van Nes, J. 2017. Pauline Language and the Pastoral Epistles. A Study of Linguistic Variation in the Corpus Paulinum. Linguistic Biblical Studies 16. Leiden: Brill.

Van Neste, R. 2004. Cohesion and Structure in the Pastoral Epistles. London: T\&T Clark. 
Van Oyen, G. 2011. The Character of Eve in the New Testament: 2 Corinthians 11.3 and 1 Timothy 2.13-14. Pages 14-28 in Out of Paradise. Eve and Adam and Their Interpreters. Edited by B. Becking and S. Hennecke. Sheffield: Sheffield Phoenix Press.

Wagener, U. 1994. Die Ordnung des "Hauses Gottes". Der Ort von Frauen in der Ekklesiologie und Ethik der Pastoralbriefe. Tübingen: Mohr.

Walker, P.L. 2012. The Pastoral Epistles Revisited, Part I-II. European Journal of Theology 21:4-16, 120-32.

Wall, R.W. 2004. 1 Timothy 2:9-15 Reconsidered (Again). Bulletin for Biblical Research 14:81-103.

Waters, K.L. 2004. Saved through Childbearing: Virtues as Children in 1 Timothy 2:11-15. Journal of Biblical Literature 123:703-35.

Wilder, T.L. 2004. Pseudonimity, the New Testament, and Deception. An Inquiry into Intention and Reception. Lanham: University Press of America.

Wilder, T.L. 2010. Pseudonimity, the New Testament, and the Pastoral Epistles. Pages 25-51 in Entrusted with the Gospel. Paul's Theology in the Pastoral Epistles. Edited by A.J. Köstenberger et al. Nashville: B\&H Publishing Group. Wilshire, L.E. 1988. The TLG Computer and Further Reference to A Y $\Theta E N T E \Omega$ in 1 Timothy 2.12. New Testament Studies 34:120-34.

Winter, B.W. 2003. Roman Wives, Roman Widows. The Appearance of New Women and the Pauline Communities. Grand Rapids: Eerdmans.

Wolters, A. 2000. A Semantic Study of $\alpha \dot{v} \theta \varepsilon \dot{v} \tau \eta\rceil$ and Its Derivatives. Journal of Greco-Roman Christianity and Judaism 1:145-75.

Zamfir, K., and J. Verheyden. 2008. Text-Critical and Intertextual Remarks on 1 Tim 2:8-10. Novum Testamentum 50:376-406. 